Олена Пожарицька

ORCID: orcid.org/0000-0003-4820-8129

DOI 10.31558/1815-3070.2021.41.22

УДК $811.111^{\prime} 367: 17.022 .1: 821.111(73)$

\title{
ВІЗУАЛЬНЕ МИСТЕЦТВО ТА ВІДЕОГРА ЯК ВИТОКИ НОВИХ ЖАНРІВ ДИГІТАЛЬНОЇ ПОЕЗІї
}

Подана розвідка спрямована на порівняльне дослідження візуальних/відео- звукових/візуально-звукових віршів та віршів-відеоігор як типових жанрів дигітальної поезіі. У прочесі роботи зроблено такі висновки. У той час, як візуальні/відео-звукові/візуальнозвукові вірші сягають корінням візуального мистецтва та експериментують з ним, велика роль, яка відводиться саме мовним компонентам у них, підкреслює необхідність виокремлення їх в окремий жанр саме дигітальної поезії, а не візуального мистецтва. Вірші-відеоігри характеризуються такими типовими рисами цифрової поезї, як людичність та інтерактивність, щуо уможливлюють новий рівень читацької імерсії.

Ключові слова: візуальні/відео-звукові/візуально-звукові вірші, вірші-відеоігри, інтерактивність, людичність, дигітальна поезія, імерсія.

Постановка проблеми. Новітні комп'ютерні технології, що отримують ще більший розквіт у двадцять першому столітті, сприяють не лише технічному прогресу у побутовій сфері життя людини, але торкаються і творчої сфери людської діяльності, змушуючи мовознавців та літературознавців переосмислювати самі концепції розуміння творчості, аби охопити усі нові форми ії проявлення. Дигітальна, або цифрова література, посунула рамки, типові для літератури як форми мистецтва взагалі, та стала новим етапом розвитку творчого пошуку.

Аналіз останніх досліджень. Ще до появи дигітальної літератури в інтернеті, Дж. Ландоу аргументував, що гіпертекстуальність цифрових творів продовжує постмодерністську теорію (Landow). Джей Девід Болтер вважав, що гіпертекстуальність охоплює, зокрема, постструктурні концепції відкритого тексту (Bolter). Характерна для цифрової літератури мультимодальність стає предметом аналізу сучасних лінгвістичних досліджень (Е. Гіббонс, Ф. Крамер, Кр. Функхоузер та ін.). Дослідники сперечаються, чи то треба вивчати код творів окремо (Кр. Функхоузер), чи код та текст є невід'ємними частинами одного цілого (Е. Аарсет).

Попри великий внесок дослідників як в Україні, так і за ії межами у розвідки з дигітальної літератури, зауважимо недостатню увагу до дигітальної поезії як окремого роду дигітальної літератури та до її жанрів. Актуальність даної роботи підсилюється практичними потребами лінгвістичного пошуку закономірностей репрезентації поетичних творів за допомогою комп'ютеру. Дана стаття продовжує дослідження автора 3 дигітальної літератури, концентруючись саме на дигітальній поезії. Метою представленої розвідки є визначення принципів виокремлення таких жанрових підвидів дигітальної поезії, як візуальні та візуальнозвукові вірші, а також вірші-відеоігри. Завдання дослідження мотивовані його метою і полягають в окресленні терміну «дигітальна поезія» та іiі базових характеристик та основних жанрів, висвітлення історичних витоків візуальних та візуально-звукових віршів, а також віршів-відеоігор, аналіз типових творів у даних жанрах 3 визначенням лінгвальних та позалінгвальних принципів їхньої структурної організації.

Об'єктом роботи виступає сучасна дигітальна поезія. Предметом - два типові її жанри візуальні та візуально-звукові вірші та вірші-відеоігри.

Матеріалом роботи обрано вірші «This is how you will die» (Nelson "This is how you will die") та «game, game, game, and again game» Джейсона Нельсона (Nelson "game, game, game, and again game"); «V[R]ignettes» Мез Бріз (Breeze); вірш «The Buoy» (Morran "The Buoy") та вірш-перфоманс «A Brief History of How Life Works» Мередіт Морран (Morran “A Brief History 
of How Life Works"); вірш-інсталяція «Wordfall, Stonetale» Цянсюнь Чень (Chen "Wordfall, Stonetale") та їі твори циклу «Shan Shui» (Chen "Shan Shui").

Виклад основного матеріалу дослідження. У той час, як електронна література представляє собою літературні твори, створені за допомогою комп'ютерних технологій, або такі, для читання яких необхідні сучасні комп'ютерні прилади (Pozharytska, "Computer Literature as a New Modus of the Readers' Existence"; Pozharytska, "Fanfiction as ludonarrative: fanwriters as gamers"), дигітальна поезія охоплює собою поетичні твори даного плану. Така поезія може бути представлена на дисках, у галереях, інсталяціях або програватися у вигляді фільмів чи коротких кліпів, в інтернеті або на мобільних додатках. Зауважимо, що на початку свого існування, цифрова поезія спиралася на стохастичні тексти німецького математика Тео Лутца, що аналізує Кр. Функхоузер у книзі «Prehistoric Digital Poetry» (Funkhouser, "Prehistoric Digital Poetry"). Використання цифрових платформ сприяло таким головним рисам дигітальної літератури та поезії, як: гіпертекстуальність, полікодовість, процесуальність як постійна зміна форми у процесі читання та залежність у цьому плані від читача (Block) (іноді твори дигітальної літератури не мають кінцівки або вона настільки відстрочена, що в читача немає можливості ії дізнатися), зв'язність (нерозривність та взаємопов'язаність між собою як один з проявів інтерактивності, що бере початок у поетичних іграх у Нюрнберзі 17 ст., епістолярному романі 18 ст. та салонній літературі 19 ст. (Cramer), а іноді навіть колективне співавторство (один митець пише код, інші його доповнюють та змінюють семантику твору, як це сталося 3 віршем Н. Монтфорта "Taroko Gorge").

У той час як $Є$. Нікітін ігнорує медіальні особливості дигітальної поезії, розглядаючи ії як «субкультуру», «поезію, опубліковану в мережі, яку читають та рецензують користувачі Мережі та яка має літературні здобутки з точки зору користувачем Мережі» (Nikitin 181), зауважимо неможливість розгляду дигітальної поезії без медій, за допомогою яких вона була створена. Так, Е. Шмідт (Schmidt) підтримує позицію Р. Сімановські про розподіл цифрової літератури на три категорії: дигіталізована, дигітальна та мережева література (Simanowski "Interfictions" 17-20). Перша 3 них написана на папері та може бути надрукована без загублення змісту, друга залежить від комп'ютерних технологій, а третя заснована функційно та естетично на принципі інтерактивності. Р. Сімановські пропонує також додатковий термін «інтерфікшнз» - interfictions - для гіпертекстової прози (ibidem). Окремо постають тексти, що самі продукуються комп'ютерними програмами, певним чином автоматизовано (Schmidt; Simanowski "Concrete poetry in analog and digital media"). У свою чергу, зауважимо, що не зовсім погоджуємося з інтерпретацією Г. Шмідта та Р. Сімановські «дигіталізованої літератури» як окремої категорії, адже по суті така література ніяк не відрізняється від традиційної, друкованої, яка також потрапляє до інтернет-простору у процесі оцифровування книжок, наприклад, бібліотеками. Однак, не можна не погодитися з тим, що жодного відношення до дигітальної літератури такі твори не мають. Щодо «інтерфікшнз» та мережевої (інтерактивної) літератури, яка вимагає від читача брати участь у ії написанні, скажемо, що не бачимо реальної необхідності у розмежуванні сучасної цифрової літератури за принципом інтерактивності, адже такий у більшій чи меншій мірі є властивим більшості дигітальних творів.

Один з видатних цифрових поетів Нік Монтфорт прямо вказує, що «поєднує написання вірша з використанням комп'ютера» (Repantis). Водночас, сама цифрова поезія, на його думку, «не має бути вищою розуміння пересічного громадянина, проте має бути дещо складною та викликати дезорієнтацію» (ibidem). Зрозуміло, що надмірне вживання цифрових технологій може призвести до «технологічного кічу», що стоїть на заваді розуміння ідеї твору, про що попереджає Роберто Сімановські (Simanowski "Concrete poetry in analog and digital media").

На основі різного ступеню людського та комп’ютерного внеску у фінальний твір та його інтерактивності нами було виокремлено сім базових жанрів дигітальної поезії: генеративна поезія; поезія-переробка; поезія-код (або кодопоезія); візуальні та візуально-звукові вірші; вірші-відеоігри; ризомні вірші; гугл-інженована поезія. Зазначимо, що, як показує проведений 
аналіз, головною відмінністю між дигітальними мистецтвом та дигітальною поезією стає опір літературного твору на мовний код.

У даній роботі ми розглянемо візуальну та відео-звукову поезію та вірші-відеоігри як одні 3 типових сучасних жанрів цифрової поезії.

Мультимодальність дигітальної поезії надає цілу низку різних можливостей для поєднання візуального та текстового планів у віршах. Зауважимо, що ще В. Блейк ще у 18 столітті ілюстрував свої вірші задля більшої виразності. Жанр «візуальних та відео-звукових (або візуально-звукових) віршів» включає в себе вірші, де акцентується поєднання вербального та невербального елементів, а ілюстрація - художня чи звукова, - по суті, несе не менш важливе навантаження, ніж вербальні елементи.

Сюди віднесемо вірші та перформанси Мередіт Морран (Morran) з Нью-Йорку, яка неодноразово ставала призеркою фестивалів дигітальної літератури (SXSW, Electronic Literature Organization Conference та ін..). Навіть перша сторінка ії̈ презентації про себе оформлена у вигляді тексту, що редагується у процесі того, як він відіграється на екрані. Читач бачить текст, що набирається на екрані, ілюстрації, які авторка бажає показати, та чує її голос, як вона зачитує інформацію на екрані (див. рис.1). Такого ж «візуальноперформативного» плану і творчі роботи Мередіт.

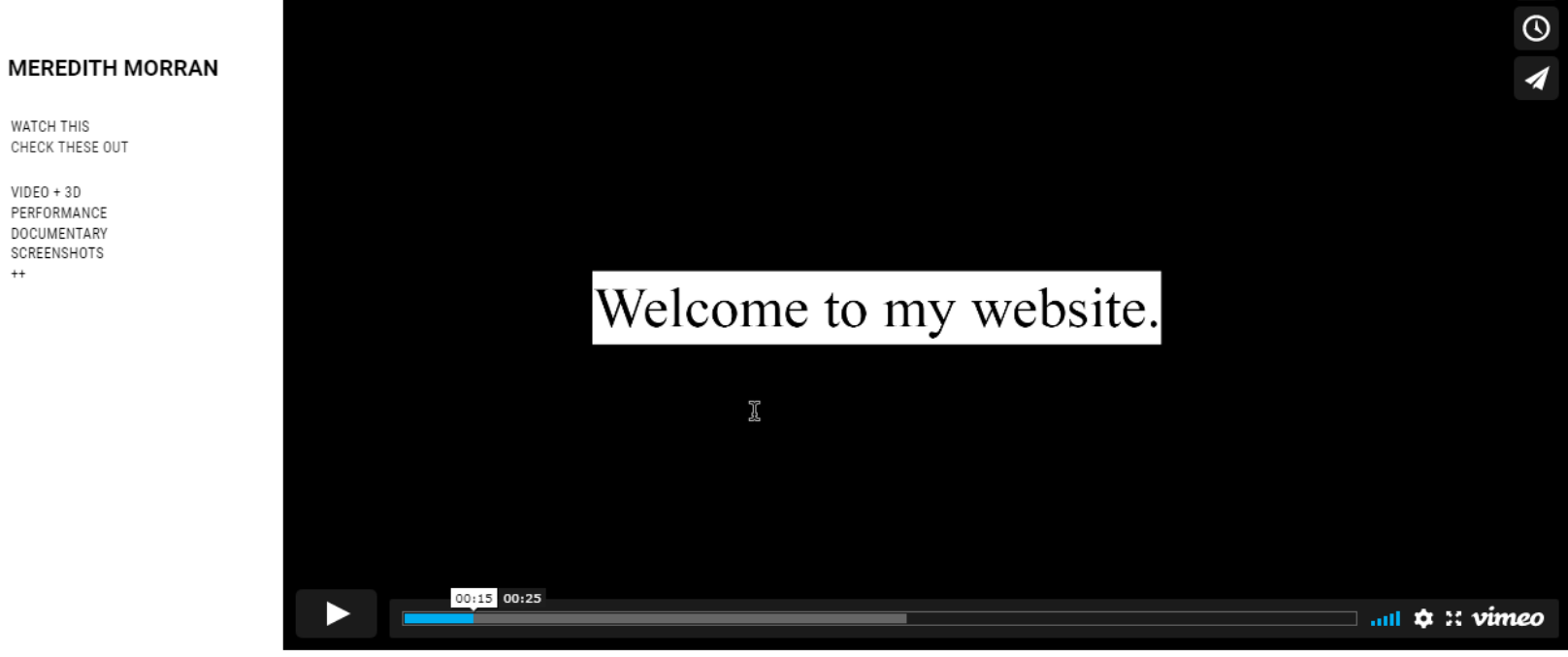

Рис.1. Титульна сторінка самопрезентації поетеси Мередіт Моран

Ïї вірш “The Buоy” (Morran, “The Buoy”) - це по суті поетичне абстрагування за допомогою діаграм та схем, що тісно переплетені з вербальними засобами художньої виразності типу каламбурів (buoy - boy) (див. рис. 2).

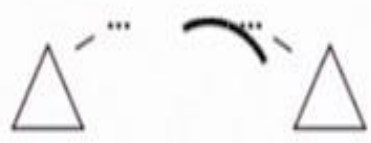

Figure 2.0

One buoy talking to another buoy

Рис.2. Знімок екрана з віршу М. Морран Тhe Виоу 
“A Brief History of How Life Works” (див. рис.3) цієї ж авторки поєднує у собі вербальні елементи з відеорядом з текстовими фрагментами, Powerpoint презентацією та фотографіями, розмірковуючи про сенс життя та особисту травму дитинства (нетрадиційна орієнтація дівчини).

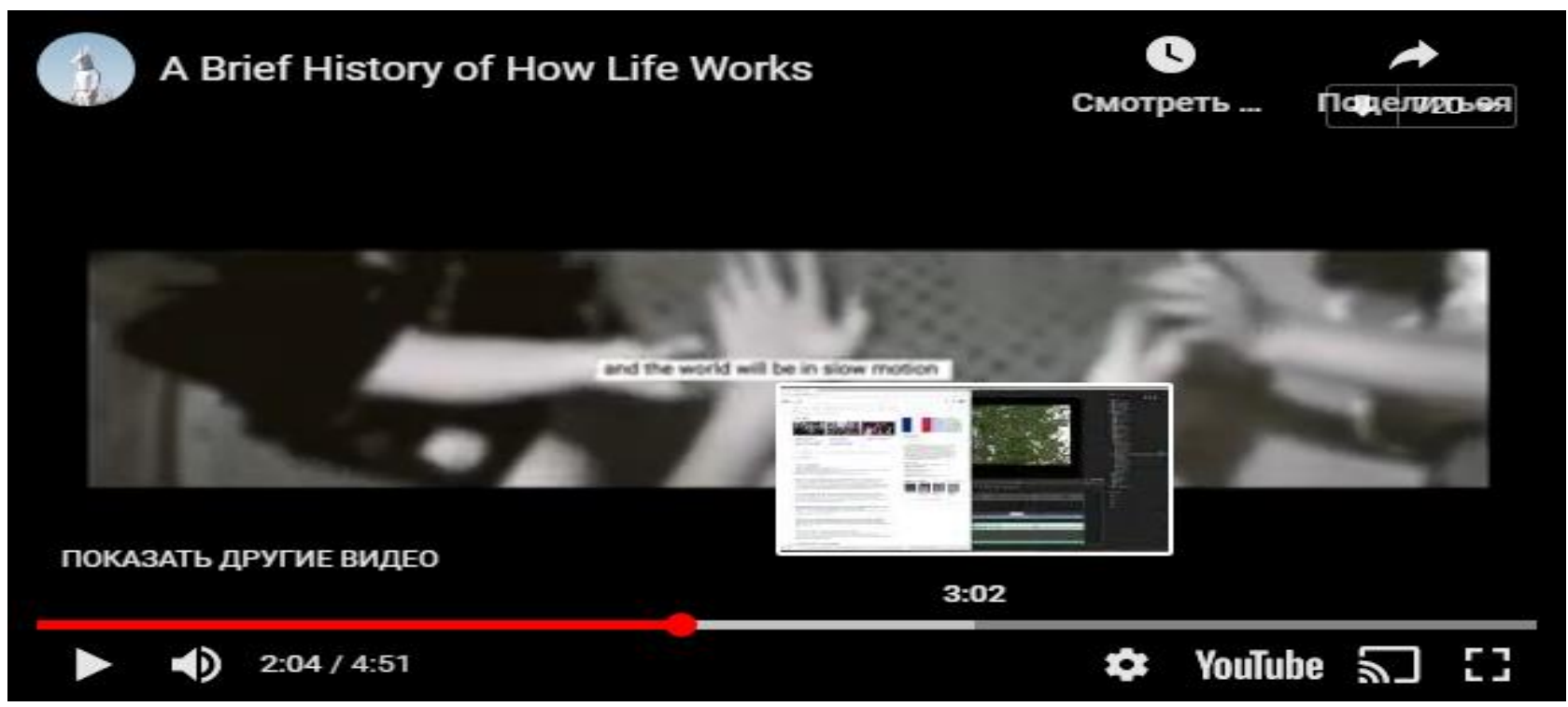

Рис. 3. Знімок екрана з віршу-перформансу М. Морран A Brief History of How Life Works

Цянсюнь Чень (Qianxun Chen), сучасний китайський «медіамитець, програміст та дослідник», як вона сама себе характеризує, створює твори на перехресті мови, мистецтва та цифрових технологій, фокусуючись на генеративній поетиці та алгоритмі естетиці. Так, іiі твори, можна сказати, позбавлені мовних меж, адже вони однаково зрозумілі носіям будь-якої мови. Знання англійської стануть у нагоді, але без китайської читач також зрозуміє авторську ідею. Її роботи - це мультимедійні інсталяції і вірші, що змінюються при кліканні мишкою по будь-якому з ієрогліфів на екрані. У першому типі з перелічених творів перед читачем розгортаються відеофрагменти, що комбінують мовні та позамовні елементи - звуки, символи, картинки. Так, твір “Wordfall, Stonetale” (2015) (Chen, “Wordfall, Stonetale”) - це інсталяція 3 відеофрагментом води, що біжить, а перед очами читача 3'являються в’єтнамські ієрогліфи (прочитати які неможливо через швидкість їх зміни), що змиваються вниз водою. Потім перед читачем постають листи з великою кількістю слів та ієрогліфів, що ілюструють людську пам'ять. Усі зміни картинок проходять під шум падаючої води (див. рис. 4). Авторка у власному англомовному аналізі підкреслює, що даний іiі твір показує, як плин віків та комунікація - в образі води - закарбовують певні слова у людській памяті. «Мова формує історію, а історія мову, як вода точить каміння,» - вказує пані Чень.

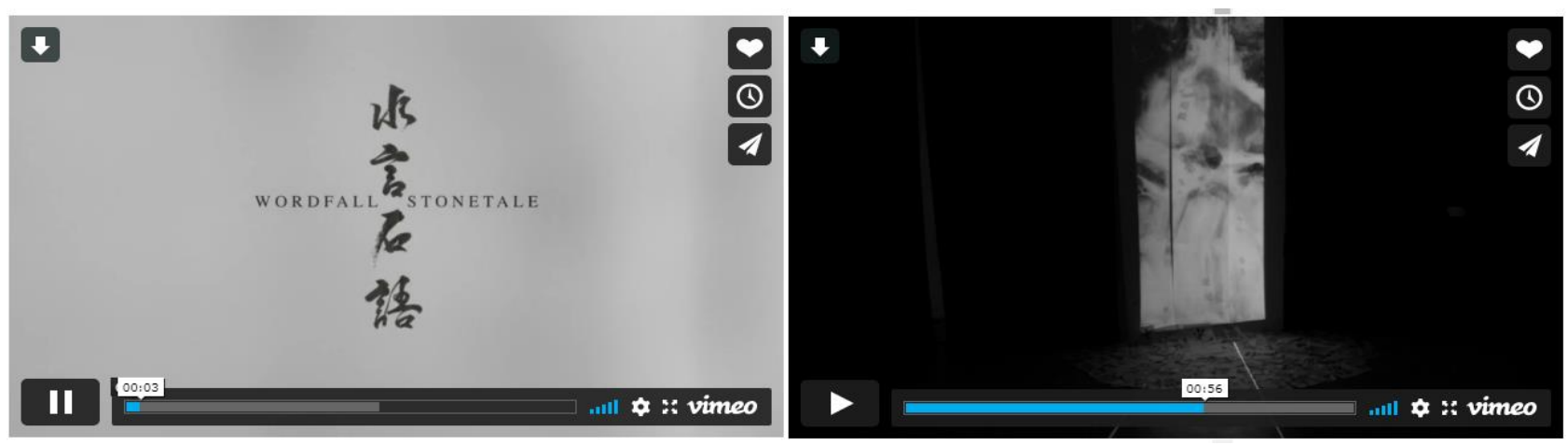

Рис. 4. Скріншоти з візуального віршу Wordfall, Stonetale Цянсюнь Чень 
Ïї твори циклу «Shan Shui» (Chen, “Shan Shui”) ближчі до традиційного розуміння поезії, адже вони представляють собою вірші, написані китайськими ієрогліфами (з перекладом англійською), проілюстровані типовими китайськими малюнками, що відповідають тематиці вірша. Тицяння на будь-якому слові у вірші «відкриває» новий вірш, що лірично перекликається з тим, що був до нього, та оздоблений іншою картинкою (див. рис.5).
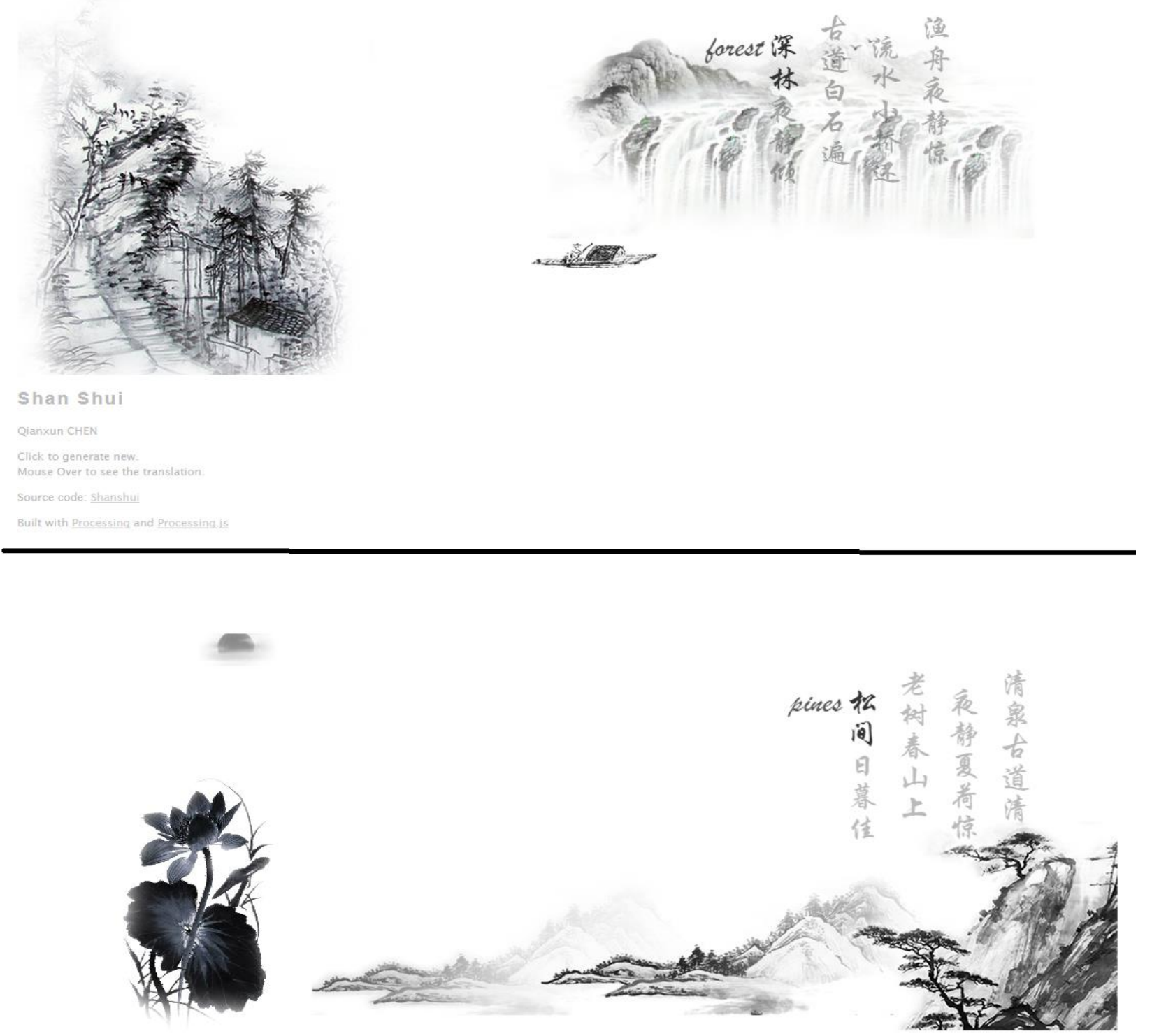

Рис. 5. Скріншоти зі збірки візуальних віршів Shan Shui Цянсюнь Чень

Можна побачити у цьому ризомну природу даної збірки, адже по суті вона сповнена гіперпосиланнями на різні вірші в їі межах. Головну відмінність між ризомними віршами, що базуються на гіперпосиланнях, та візуальною поезією вбачаємо у наближенні останньої до художнього мистецтва. Загалом, за нашими підрахунками співвідношення між візуальним/аудіальним компонентом та текстом у візуальній та візуально-звуковій поезії з урахуванням їхньої важливості йде як 3 до 2 (60\% змістового навантаження лягає на візуальнозвуковий супровід, а 40\% - на текстові елементи). Отже, візуальні та візуально-звукові вірші наближуються до художнього та звукового мистецтва, однак їхня нерозривна пов'язаність 3 мовним кодом потребує їхнього включення до різновидів дигітальної поезії.

Узагальнюючою рисою поезії в аналізованій збірці є те, що комп’ютер генерує їх за допомогою коду, написаного митцем, та сам підбирає ілюстрацію. Зауважимо, що зрощення візуального та текстового аспектів підкреслюється самою назвою циклу. У китайській shan 
позначає гору, а shui - воду. Поєднання двох ієрогліфів дає слово «пейзаж», що є як терміном для типу віршів, що описують природу, так і типом живопису.

Наступним жанром для розгляду є вірuі-вideoizpu. Ще у 60x-70x роках минулого сторіччя почали з`являтися комп'ютерні ігри типу Zork, тобто такі, що базувалися на текстових компонентах. До речі, відпочатковий код таких ігор заархівовано у бібліотеках Масачусетського інституту технологій (“Zork source code”). Цей самий тренд продовжують і поети сучасності, у кращих тенденціях постмодерну висміюючи комерційні комп’ютерні ігри. Так, наприклад, Джейсон Нельсон з Австралії, митець, поет, дослідник та викладач комп’ютерної поезії, створює свої твори саме у жанрі віршів-відеоігор. «Той факт, що я цифровий митець та письменник, дозволяє мені ламати, переосмислювати будь-які технології, речі та інтерфейси. Усе - від картинок до звуків, рух та код, механізми та інтерактив - стають текстами для поетичної гри», - каже автор (Nelson, "Digital Oddities and Creatures"). У той час, як більшості його робіт характерні інтерактивність, інтерфейс та рух як центральні текстові елементи, близько $20 \%$ його найбільш популярних творів представляють собою саме ігри. Сам автор пояснює це людичним ефектом буття, властивим грі та таким відеоігровим віршам. Такий самий ефект мають реальні життєві події та ситуації. «Слова дигітального вірша мають бути взаємопов'язані з рухом, звуком, картинкою та інтерфейсом. Якщо слова можна закарбувати на папері, і вони сформують нормальний вірш, без усіх додаткових елементів, то з таким цифровим твором щось не так.» (ibidem). Так, вірш "game, game, game, and again game” (Nelson, "game, game, game, and again game") прямо заявляє про свою людину природу вже самою назвою - «гра, гра, гра, та ще раз гра». Інший вірш - "This is how you will die" прямо постулює екзистенціальну природу сюжету. У «грі...» Нельсон використовує традиції старих ігор, де гравець стрибає та біжить крізь багаторівневий конструкт його письма, малюнків та старих домашніх кінострічок. Приз тут - не бали-очки, а саме існування у грі. Ті самі каракулі, що у Дж. Нельсона (див. рис.6), використовують Дубуффет, Тублі та Басквіат, але саме в Нельсона естетика, створена у творі, дійсно органічна та вплетена в мотив життя як такого.

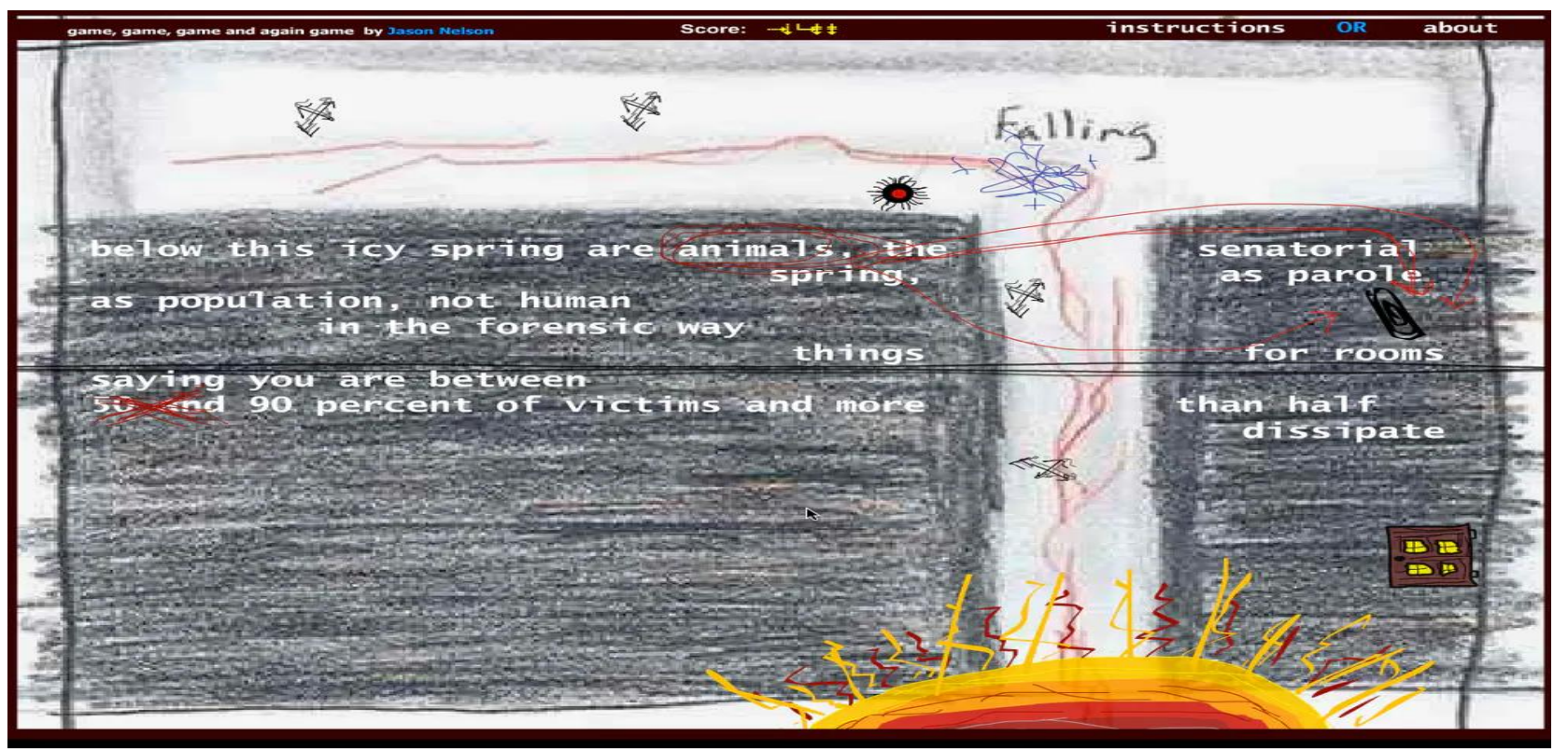

Рис. 6. Знімок екрана з віршу-відеогри "game, game, game, and again game” Дж. Нельсона

Поява таких ігор віртуальної реальності, як “Half-Life: Alyx” (“Half-Life: Alyx”) - ігор, для використання яких потрібні окуляри віртуальної реальності (VR) також сприяла розвитку поезії-відеогри. Так, австралійка Мез Бріз (Mez Breeze) «оживила» свої вірші, запакувавши їх у серію маленьких історій, які доступні в окулярах віртуальної реальності. На це натякає вже сама назва іiі поезій «V[R]ignettes» - «Замальовки/Етюди у віртуальній реальності (VR)» (Breeze). Побачити ці вірші можливо лише в окулярах віртуальної реальності у браузері у $3 Д$. Кожна з таких «Замальовок» поєднує поетичний текст, моделі у ЗД та звуки, що сприяють 
атмосферності та більшій імерсії читача. Унизу екрану читач може тицяти на клавішу «Обрати анотацію» або просто роздивлятися навкруги в окулярах віртуальної реальності та власноруч досліджувати твори. Твір виграв приз за кращий цифровий літературний твір у Квінзлендському технологічному університеті (Queensland University of Technology Digital Literature Prize). Першою назвою твору було «A Million and Two»- «Мільйон та ще дві». У самій анотації до твору автор вказує, що кожний з віршів має сприяти «наративному наплямуванню» “narrative smearing”, де традиційні техніки розгортання історії закарбовані у ««плями» 3 кінестетичним наповненням, механікою, колажами, візуальним розмиттям, дворівневим текстом» (ibidem). Така композиція потребує від читача активної позиції, де читач сам робить вибір задля пересування від однієї історії до іншої. Дослідивши самі «Замальовки», скажемо, що багато 3 них потребують кількаразового читання, адже поетична мовна гра часто є продуктом взаємодії двох слів, читання яких стає можливим завдяки квадратним дужкам (як і у назві $V[R]$ ignette - vignette - замальовка та $V R$ - virtual reality). Такі графони додають поезії глибокості та дозволяють авторові повністю розкрити потенціал усіх значень, що можуть запропонувати мовні символи. Технологічно поезії побудовані так, що постійно вимагають від читача прямої відповіді: Do you choose to view each microstory in a $3 D$ or VR space - through a Virtual Reality headset or a mobile phone or computer monitor? - Чи Ви хочете подивитися кожну мікроісторію у ЗД чи у віртуальному просторі - крізь окуляри віртуальної дійсності чи на мобільному телефоні чи на комn'ютерному моніторі? Do you set each microstory to autopilot, or navigate the experience through manual annotation click-throughs and spatial manipulations? Чи Ви обираєте автопілотування - автоматичне переключення від твору до твору - чи Ви будете власноруч спрямовувати його кліканням та маніпуляціями у просторі? Do уои сhооле to use the model inspector and view the microstories without any post-processing effects, or in wireframe? - Чи Ви обираєте використовувати функиію моделювання без пост-творових ефектів чи Ви хочете бачити контури рисунків? Dо уои choose to enable audio? Чи включити aydio? Do you read only the title fields or entire paragraphs? - Ви читаєте лише назви або цілі абзаџи? (переклад мій-Пожарищька О. О.). Такий підхід дозволяє прочитати кожний твір декілька разів, кожного разу по-новому, проте закільцьованим та закоркованим авторським набором позицій, що запрограмовані у творі відразу. Так, обираючи читання лише першого рядку кожної анотації, читач отримує мінімально поетичний твір. Якщо читач обирає прочитати усі твори, то його розуміння буде край іншим. Також іншими за наповненням будуть і твори типу "Wracking in the Upper Bubble" (Breeze), де Ви можете прочитати напис на стіні (див. рис.7), а можете маніпулювати простором, використовувати наближення, ротацію чи інший масштаб для більшого поринання у художній світ поетеси.

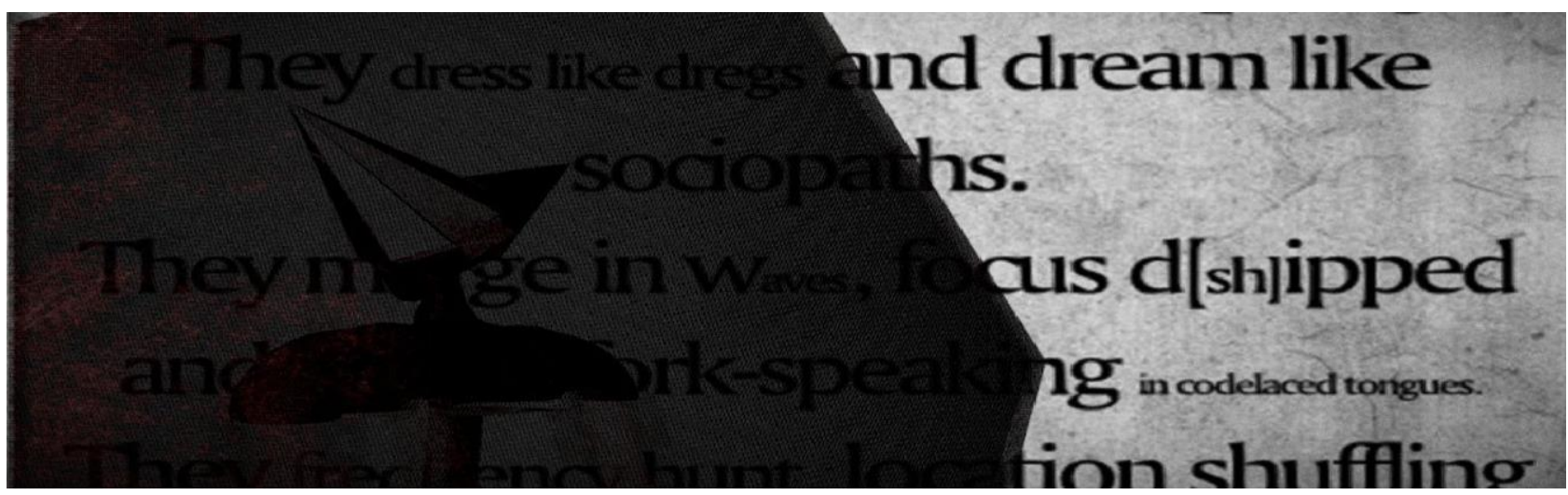

Рис. 7. Знімок екрана з віршу-відеогри V[R]ignettes Мез Бріз

Граючи $з$ цією «Замальовкою», можна отримати наразі наступний вірш:

...they wrack differently in the Upper Bubble. They move weirdly too, all broken shoulders and splayed display. They dress like dregs and dream like sociopaths.

They merge in waves, focus d[sh]ipped and wired, fork-speaking in codelaced tongues. 
They frequency hunt, judgment-makers in loose b[l]oomings. Location shuffling through b[g]aited eyes. Laconic bumbling + noise parading.

With opinions bred in cloisters, their odd bra[cken]yish voices cast from long shear faces.

They wheedle and croon and spin their blather to angels while... ...wracking differently in the Upper Bubble (ibidem).

Проведений аналіз показує, що неможливо відірвати будь-який вірш-історію від картинки поряд 3 ним. Ви можете використовувати телепортацію в окулярах віртуальної дійсності та роздивлятися навкруги, але без них Ваші враження будуть зовсім іншими, проте сам твір залишиться незмінним.

Про даний жанр дигітальної поезії казав ще К. Функхоузер, коли знайомив своїх студентів 3 дигітальною поемою Джима Ендрюса «Asteroids»: «Що є перед Вами? Відеогра 3 фрагментованою мовою, подана як поезія - чи поезія, реалізована як тип гри без конкретної структури?» (Funkhouser, "New Directions in Digital Poetry”). Це питання є одним з базових у сучасній дигітальній поезії.

Як зазначає Й. Хейзінга, «ігровий елемент настільки іманентний самому існуванню поезії та будь-яка форма поетичного настільки тісно пов'язана зі структурою гри, що їх внутрішню зв'язність можна булло б назвати майже нерозривною, а термінам «гра» та «поезія» у такому взаємозв'язку погрожувала б втрата незалежності свого значення.» (Huizinga). Поезії-відеоігри характеризуються типовим для відеоігор управлінням та підвищеною людичністю та симулятивністю. Як вірно вказує Т. Фортуна, «людичність є потребою людини у будь-якому віці, а не лише для урізнобарвлення життя» (Fortuna 11). Таким чином, окрім естетично-етичної спрямованості, типової для літератури взагалі, дигітальна поезія імпонує читачеві особливою ігровою природою, як вірно вказує В. Самохіна, «сучасний світ неможливо уявити без Homo Communicens - людини, що спілкується, Homo Artifex - людини, що творить, Homo Ludens - людини, що грає, Homo Ridens - людини, що сміється» (Samokhina 6). Дійсно, у творах дигітальної поезії завдяки симулятивності, імерсивності, людичності та інтерактивності як автор, так і читач виконують дані ролі, разом створюючи новий мінливий комунікативний простір цифрового твору.

Отже, проведене дослідження дозволяє зробити такі висновки. Візуальна та візуальнозвукова поезія представляє собою мультидисциплінарний рубіжний жанр дигітальної поезії, наближений до художнього та звукового мистецтва. Велика роль, яку несе мовний код не дозволяє ігнорувати даний жанр у межах дигітальної поезії. Типовим для цього жанру є мовна гра, каламбур та іронія, у тому числі на стиці двох медій - візуально-звукової та мовної сфер. Даному жанрові притаманна полікодовість, проте менш властива інтерактивність 3 читачем.

Вершиною інтерактивності у межах дигітальної поезії вважаємо вірші-відеоігри. Попри велику наявність полікодовості повідомлення - використання усіх можливих кодів та медій, які дозволяють сучасні технології, - поезія-відеогра надає читачеві можливість не лише вибору, але й різного типу пересування у сфері дигітальної поезії, що сприяє ії імерсивності та виводить авторсько-читацьку взаємодію на новий рівень. Читачі стають тими «wreader»- зрощування зі слів writer + reader, що співпрацюють 3 автором (або імітовано співпрацюють 3 автором, як у готових віршах-відеоіграх, обмежених авторською фантазією), про яких писал Дж. Ландоу, що розчинюють текст (Landow), хоча б у межах обраного шляху крізь побудований всесвіт відеогри-віршу. Тоді як ігровий початок у мистецтві проявляє себе у грі змістів, натяках, підтекстах, загадковості та нестандартності сюжетної побудови твору, у тому, як співіснують в одному творі трагедія та кумедія, у творах дигітальної літератури він віддзеркалюється ще й у самій формі подачі цифрової поезії.

Перспективами роботи вважаємо порівняльне дослідження віршів-відеігор та відеігор як таких з точки зору комунікативного навантаження та структури їхнього людонарративу. 


\section{References}

Block, Friedrich. "Auf hoher See in der Turing-Galaxie. Visuelle Poesie und Hypermedia". Text und Kritik. Visuelle Poesie. Ed. by Arnold, Heinz Ludwig. Sonderband Nr. 9 (1997): 51-64. Print.

Bolter, J. David. Writing Space: Computers, Hypertext, and the Remediation of Print. Routledge; 2nd edition, 2001. Print

Cramer, Floria "Warum es zuwenig interessante Netzdichtung gibt". Netzliteratur, www.netzliteratur.net/cramer/karlsruher_thesen.html. Web. 2 Feb. 2021.

Fortuna, T.R. O Lugar do brincar na educação infantil. Revista Pátio Educação Infantil, ano IX, n.27, abr / jun. 2011 (2011): 11-15.

Funkhouser, C. T. Prehistoric Digital Poetry: An Archaeology of Forms, 1959-1995. University of Alabama Press, 2007. Print.

Funkhouser, C. T. New Directions in Digital Poetry. Bloomsbury Publishing, 2012. Print.

Huizinga, Johan. Homo Ludens: A Study of the Play-Element in Culture. Angelico Press, 2016. Print.

Landow, George. Hypertext: The Convergence of Contemporary Critical Theory and Technology. Johns Hopkins University Press, 1992. Print.

Nelson, J. Digital Oddities and Creatures. www.secrettechnology.com/about.html. Web. 12 Sept. 2020.

Nikitin, Ievheniy. "O kul'ture chteniya v sets. Setevyie chitateli i kritiki (About the culture of reading online. Web-readers and critics)" Setevaya slovesnost', www.netslova.ru/nikitin_e/o_kulture.html, 20.05.2003. Web. 2 Feb. 2021.

Pozharytska, O. "Computer Literature as a New Modus of the Readers' Existence". Science and Education : a New Dimension. Philology. IV (23). Issue 100 (2016): 27-32.

Pozharytska, O. "Fanfiction as ludonarrative: fanwriters as gamers". Science and Society. N 1. Vol. 1 (2017): 100-107.

Repantis, Kate. "Computer-Generated Poetry Liberates Readers, Attracts Coders" SLICE.MIT.EDU. (30 Apr. 2014), alum.mit.edu/slice/computer-generated-poetry-liberatesreaders-attracts-coders. Web. 8 Feb. 2021

Schmidt, Enrike "Bukval'naya (ne)dvyzhymost': Dyhytal'naya poezyya v RuLyNete. (Literal (Im)mobility: Digital poetry in RuLiNet)" Russian Literature LVII (2005): 423-440. Print.

Schmidt, Henrike. "Der Computer als "evokatorisches Objekt". Sprachmaschinen und automatisierte Kommunikation in der russischen Netzliteratur." Anzeiger für Slavische Philologie XXXI (2003): 33-62. Print.

Simanowski, Roberto. Interfictions. Vom Schreiben im Netz. Frankfurt am Main, 2002. Print.

Simanowski, Roberto. "Concrete poetry in analog and digital media." dichtung-digital (2003), www.dichtung-digital.de/2003/parisconnection/concretepoetry.htm. Web. 7 Feb. 2021

Samokhina, V. O. Zhart u suchasnomu komunikatyvnomu prostori Velykoyi Brytaniyi $i$ SShA: tekstual'nyy ta dyskursyvnyy aspekty. (Jokes in the modern communicative space of Great Britain and the USA) Diss. Kyiv Taras Shevchenko National U, 2010. Print.

\section{List of Sources}

Breeze, Mez. V[R]ignettes. mezbreezedesign.com/vr-literature/vrignettes. Web. 12 Sept. 2020.

Chen, Q. Shan Shui, curamag.s3.amazonaws.com/renderings/shanshui/ShanshuiV2/index.html. Web. 12 Sept. 2020

Chen, Q. Wordfall, Stonetale. 2015, chenqianxun.com/wordfallstonetale. Web. 12 Sept. 2020.

Half-Life: Alyx. half-life.com/en/alyx. Web. 12 Sept. 2020.

Morran, Meredith. A Brief History of How Life Works, meredithmorran.com/a-brief-history-ofhow-life-works-1. Web. 20 Jan. 2020.

Morran, Meredith. The Buoy, elmcip.net/sites/default/files/media/work/media/buoy-excerpt.mp4. Web. 20 Jan. 2020.

Morran, Meredith. Hello. meredithmorran.com/homepage. Web. 20 Jan. 2020 
Nelson, J. "game, game, game, and again game" Electronic Literature Collection. Volume 2, https://collection.eliterature.org/2/works/nelson_game.html. Web. 12 Sept. 2020.

Zork source code, 1977. archivesspace.mit.edu/repositories/2/archival_objects/347748. Web. 12 Sept. 2020.

\section{VISUAL ART AND VIDEOGAME AS THE ORIGIN OF NEW DIGITAL POETRY GENRES \\ Olena Pozharytska \\ Chair of English Grammar, Romance-Germanic Faculty, Odesa Mechnikov National Univer- sity, Odesa, Ukraine}

\section{Abstract}

Background: Modern technologies have not only helped modern people in their daily routine, but also evoked a new form of literature, basing on digital devices, written with their help or performed by them. Thus, digital literature and poetry in particular are more and more frequently becoming the object of linguistic interest.

Purpose: The purpose of the given article is to determine the principles of singling out such genres of digital poetry as visual/video-and-audio/visual-and-audio poems and poems-videogames.

Results: Visual/video-and-audio/visual-and-audio poems make up a borderline genre in digital studies, encompassing both language means and visual and audio art. However, an important role played by language as a specific type of code expressing the idea of the poem permits classifying such works of art as digital poems. They are characterised by puns and irony, often resting on both visual/visual-and-audio and language means. Poems-videogames, in their turn, give readers more interactivity and have a ludative nature, stemming out of their videogame-like form and multimodality, which enhances the readers' immersion while reading/playing the poem.

Discussion: As the prospects of our investigation, we see a comparative research of poemsvideogames and regular videogames from the point of view of their ludonarratives' communicative loading and structure.

Keywords: visual/video-and-audio/visual-and-audio poems, poems-videogames, interactivity, ludative nature, digital poetry, immersion.

Vitae

Olena Pozharytska is a $\mathrm{PhD}$, Candidate of Philological Sciences, Associate Professor, Odesa Mechnikov National University, Odesa, Ukraine. Her areas of research interests include theoretical grammar, narratology, syntax, digital literature studies, communicative linguistics and literary semantics.

Correspondence: morpo@ukr.net

Надійшла до редакції 21 лютого 2021 року Рекомендована до друку 15 березня 2021 року 